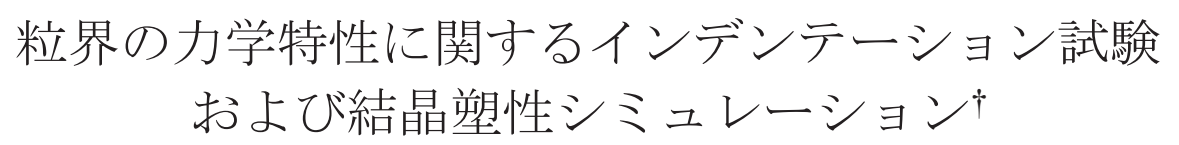

青柳 吉輝* 佐久間 翔**

\title{
Indentation Test and Crystal Plasticity Analysis on Mechanical Properties of Grain Boundary
}

by

\author{
Yoshiteru AoYAgr* and Sho SAKUMA**
}

\begin{abstract}
In this study, mechanical properties of grain boundary are evaluated by indentation tests at grain boundaries and grains consisting of the grain boundary. We find that maximum displacement of indenter at the grain boundary is different from the average of maximum displacement of the two grains. Moreover, we perform three-dimensional crystal plasticity FEM analyses on the indentation test and we discuss factors and mechanism on mechanical properties of grain boundary. Dislocation information is introduced into a hardening law of crystal in order to investigate the effect of dislocation behavior on the grain boundary. The load-displacement curves obtained by the crystal plasticity simulation predict that the maximum displacement of indenter at the grain boundary depends on crystal orientation and dislocation behavior.
\end{abstract}

\section{Key words:}

Grain boundary, Dislocation, Crystal plasticity, Indentation test, Crystal orientation

\section{1 緒言}

金属材料の力学特性は転位組織や結晶粒径などの微視 組織に大きく影響を受ける。そのため，熱処理や表面処 理などによる微細組織制御を行うことによって，優れた 力学特性を有する材料の創製が可能となる. しかしなが ら, 従来の引張り試験などを用いた力学特性の評価手法 では巨視的な力学特性しか得ることができず, 固溶強化, 析出・分散強化, 加工硬化および結晶粒微細強化といっ た微視組織による影響を局所的に観察することは困難で ある．金属材料の更なる力学特性向上のためには，転位 や粒界などの微視組織が力学特性に与える影響について 局所的検討が必要である. また, 超微細結晶粒材料や超 微細機械装置など，粒界の影響が大きいマイクロ〜ナ) オーダの現象を数值解析的に観察するために, 粒界や転 位などの微視組織を直接表現可能なマルチスケールモデ ルの構築に期待が寄せられている.

材料の力学特性を微視的に評価するために，材料表面 の局所領域に圧子を押込むインデンテーション法が用い られている1), 2), 一方, 多結晶金属材料における結晶方位 分布は巨視的な材料特性に影響を及ぼし, 結晶方位の測 定手法としては, X 線回折法, 電子線回折法や電子線後 方散乱回折(EBSD)法 3) 5)などが挙げられる. EBSD 法は, 従来の結晶方位測定手法と比較して測定時間および空間 分解能に優れており, また, 結晶方位分布が容易に得ら
れる．材料特性評価において結晶方位分布は非常に有用 な情報であり，加工集合組織，結晶粒の形状および個々 の粒界における結晶方位差だけでなく, 粒内における結 晶方位の変化なども明らかになる.

計算機の発達に伴いインデンテーション試験について も数值解析を手掛かりにした研究が行われている. 連続 体力学に基づく有限要素法を用いたインデンテーション 試験に関する数值解析の結果から, 圧痕下部における相 当応力分布などが観察されている6). 従来の連続体力学を 用いた数值解析では, 巨視・等方的な弾性率や降伏応力 などで表現される均質材料モデルが使用されることが多 い. しかしながら, 連続体力学に基づく材料モデルでは, 結晶粒や結晶構造などの微視的情報を考慮するのは困難 である。結晶構造を直接表現するために，結晶塑性論を 用いたインデンテーション試験に関する数值解析が行わ れているが，それらの多くは単結晶を想定している7)，8). また，分子動力学法を用いたナノスケール領域における 数值解析が行われており, 圧子接触の初期段階における 転位核生成などが再現されている 9), 10). しかしながら， 分子動力学法を用いた数值解析では, マイクロスケール での連続分布的な転位挙動を解析するのは現状の計算機 の能力では困難である. 結晶粒スケールの転位挙動や変 形挙動を表現するために, 微視的情報を導入したマルチ スケール結晶塑性モデルに関する研究が盛んに行われて

$\dagger \quad$ 原稿受理 平成26年9月5日 Received Sep. 5, 2014 C2015 The Society of Materials Science, Japan

* 正 会 員 東北大学大学院 $=980-8579$ 仙台市青葉区荒巻

Tohoku Unive., Aoba-ku, Sendai, 980-8579.

** 東北大学大学院 $=980-8579$ 仙台市青葉区荒巻

Tohoku Unive., Aoba-ku, Sendai, 980-8579. 
おり，粒径に依存した寸法効果 11)，12，転位情報を導入し た結晶塑性モデル 13) 15)，粒界の影響を考慮したマルチス ケールモデル 17) 19)などが提案されている. しかしながら， これらのマルチスケール結晶塑性モデルを用いてインデ ンテーション試験などの実際の実験条件を想定した解析 を行った例は多くない，実験結果と比較検討することに よって，モデルの妥当性の検証ならびに実験では観察が 困難な現象を考察することが可能となる.

そこで，本研究では，インデンテーション法を用いて 粒界の力学特性を評価するとともに, EBSD 法を用いてイ ンデンテーション試験後の圧痕周辺領域の結晶方位分布 を測定する。また，力学特性に対する粒界の影響因子お よび機構について検討することを目的とし，実験で得ら れた微視組織の情報を反映した結晶塑性解析を行う。材 料の微視的転位挙動を観察するために, 著者らが提案し た転位の挙動を考慮した結晶塑性モデル 19)を用いる。イ ンデンテーション試験を想定した数值解析を行うことで, 転位密度や結晶方位が粒界の力学特性に及ぼす影響につ いて考察する.

\section{2 インデンテーション試験}

\section{$2 \cdot 1$ 実験方法}

供試材には純度 99.99\%のアルミニウムを用いた. まず, $10 \mathrm{wt} \%$ 水酸化ナトリウム水溶液を用いて $10 \mathrm{~min}$ のエッチ ング処理を行い, 粒界を観察できるようにした. そして, 粒界が試験片表面に対して垂直に近づくようにファイン カッタを用いて切り出した。 切断面を\#400 のエメリ紙で 研磨した後，673 K, 2 h の条件で焼鈍処理を行い，残留 ひずみを除去した.インデンテーション試験を行う試験 片表面を\#400～\#4000 のエメリ紙および粒径 $1 \mu \mathrm{m}$ のダイ ヤモンドスラリーを用いて機械研磨を行った後，イオン ミリングによる表面研磨仕上げを行った．イオンミリン グの条件は，Ar イオンビームの試験片表面への入射角を

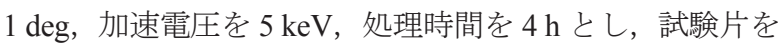
回転させながら処理した。以上の方法を用いて異なる粒 界を含む試験片を 3 種類作製し，それぞれを試料 1 , 試料 2 および試料 3 とした，以降，各試料を構成する結晶粒を 粒 $1 \mathrm{~A}$, 粒 1B, 粒 $2 \mathrm{~A}$, 粒 $2 \mathrm{~B}$, 粒 $3 \mathrm{~A}$ および粒 $3 \mathrm{~B}$ と称し, 各試料の粒界を粒界 1 , 粒界 2 および粒界 3 と称す。

まず，微小押込み硬さ試験機を用いて粒内および粒界 においてインデンテーション試験を行った。圧子には, 先端半径が $50 \mu \mathrm{m}$ の球状ダイヤモンド圧子を用い, 最大 押込み荷重を $0.294 \mathrm{~N}$ ，圧子押込み時間および除荷時間を $10 \mathrm{~s}$ および最大押込久荷重保持時間を $1 \mathrm{~s}$ とした。粒内お よび粒界の測定点間隔は圧痕直径の 5 倍以上とした。

EBSD 法を用いて, インデンテーション試験後の圧痕周 辺領域の結晶方位について測定した。本測定での測定条 件は加速電圧を $20 \mathrm{kV}$, 作動距離を $15 \mathrm{~mm}$ とし, 試験片 の観察面の法線方向に対して $70 \mathrm{deg}$ 傾けた方向から電子 線を照射した 5). また, 結晶方位分布測定における電子線 の走査間隔は，試料全体を測定寸る場合は六角形状に 3 $\mu \mathrm{m}$ ，粒内および粒界における圧痕周辺領域を測定する場
合は $0.2 \mu \mathrm{m}$ であり，それぞれ約 200,000 点および約 400,000 点の結晶方位を測定した。

\section{$2 \cdot 2$ 結果および考察}

Fig. 1 に, 試料 1, 試料 2 および試料 3 の粒内および粒 界におけるインデンテーション試験の結果（圧子の最大 押込夕深さ）を示す。図中の破線は粒 $\mathrm{A}$ および粒 $\mathrm{B}$ の最 大押込み深さの平均を表す。粒界での最大押込み深さが 破線より上に位置する場合には, 粒界を構成する結晶粒

(粒 A および粒 B）の最大押込み深さの平均值よりも粒 界の最大押込み深さの方が大きいことを意味する. 各結 晶粒で，押込み方向に対する結晶方位が異なるため, 各 結晶粒の最大押込み深さは異なっている。粒界における

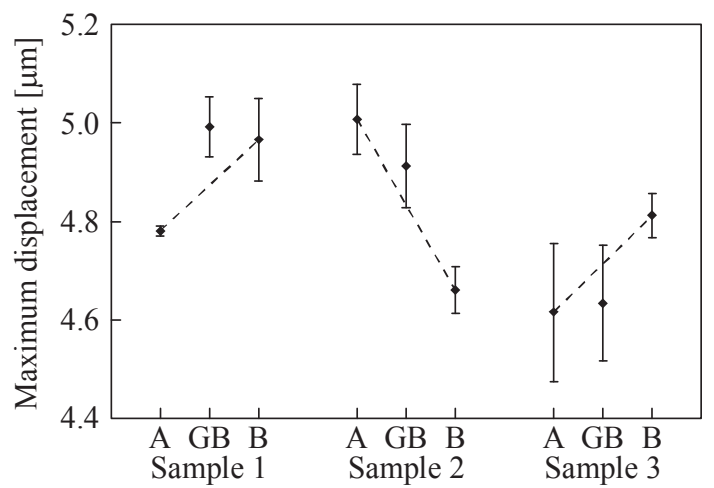

Fig. 1 Maximum displacement of indenter for the grains consisting of a grain boundary (A and B) and the grain boundary $(\mathrm{GB})$ of each sample.

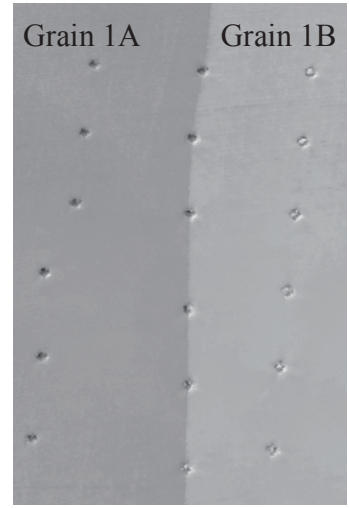

(a) Sample 1

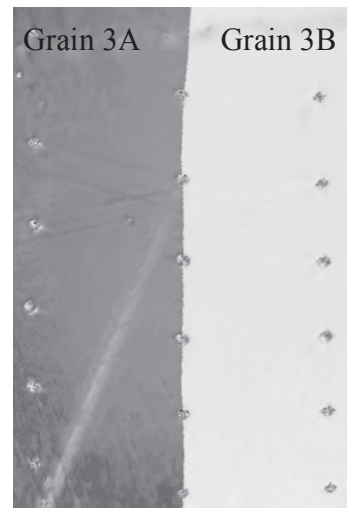

(c) Sample 3

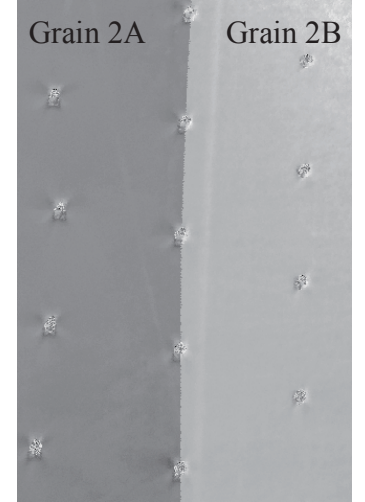

(b) Sample 2
Fig. 2 Crystal orientation for the indentation direction and arrangement of the indentation for each sample. 


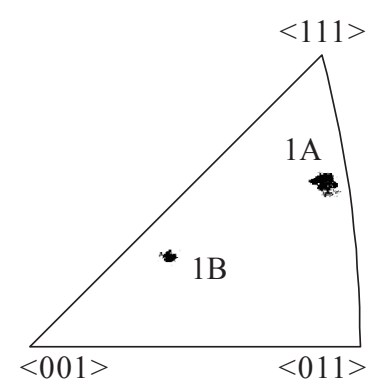

(a) Grain $1 \mathrm{~A}$ and grain $1 \mathrm{~B}$

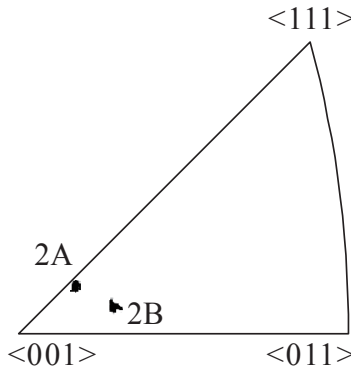

(b) Grain 2A and grain 2B

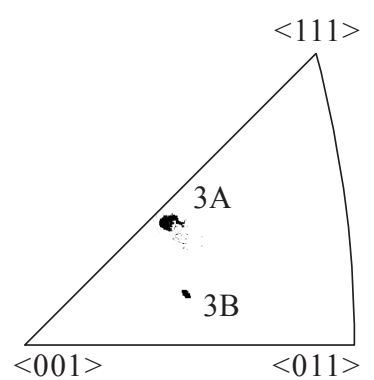

(c) Grain 3A and grain 3B

Fig. 3 Inverse pole figures for the grains consisting of the grain boundary of each sample.

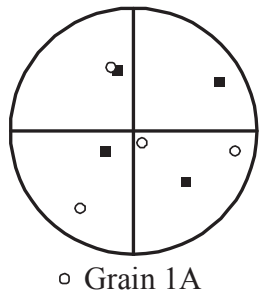

- Grain $1 \mathrm{~A}$

(a) Sample 1

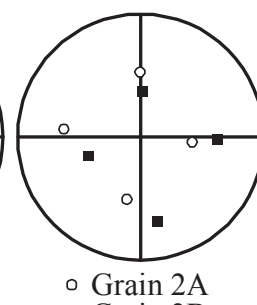

- Grain 2B

(b) Sample 2

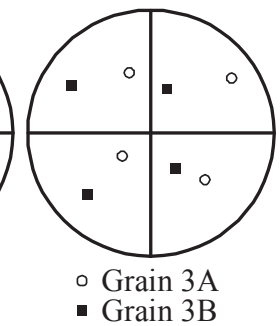

(c) Sample 3
Fig.4 Pole figures for $\{111\}$ plane of each sample.

Table 1 Euler angle of each grain consisting of the grain boundary of each sample.

\begin{tabular}{cccc}
\hline & $\varphi_{1}[\mathrm{deg}]$ & $\phi[\mathrm{deg}]$ & $\varphi_{2}[\mathrm{deg}]$ \\
\hline Grain 1A & 289.6 & 111.0 & 229.5 \\
Grain 1B & 195.9 & 24.0 & 147.7 \\
Grain 1A & 43.0 & 96.9 & 8.1 \\
Grain 2B & 232.9 & 93.3 & 346.5 \\
Grain 3A & 32.5 & 155.2 & 41.4 \\
Grain 3B & 3.3 & 23.0 & 273.6 \\
\hline
\end{tabular}

最大押込み深さは，構成粒の平均值と一致していない. 試料 1 および試料 2 では粒界の最大押込み深さが粒内の 平均值を上回り，試料 3 では下回る傾向を示した。この ことは，試料 1 および試料 2 では粒界は柔らかくなり， 試料 3 では粒界は固くなっていることを示唆している.

EBSD 法を用いて得られた試料 1 , 試料 2 および試料 3 の圧子押込み方向（紙面垂直方向）に対する結晶方位分 布を Fig. 2 に示す. 圧痕周辺の結晶方位分に関しては, 数 值解析の結果とともに次章にて示寸. Fig. 2 おける円状の 変色部分は圧痕部分であり，圧子が粒界上に押し込まれ ていることが確認できる. Fig. 3 は圧子押込み方向に対す る逆極点図あり，オイラー角で表した各結晶粒の結晶方 位を Table 1 に示す. Table 1 の結晶方位は各粒の代表点 1 点におけるデータであり, オイラー角は Bunge の定義に
よるものである. Fig. 3 および Table 1 から，本実験に用 いた試料の結晶粒はすべて異なる結晶方位であることが わかる. 粒界 1 , 粒界 2 および粒界 3 における方位差は $35.18 \mathrm{deg}, 55.21 \mathrm{deg}$ および $64.12 \mathrm{deg}$ であり，いずれも大 角粒界であった。なお，上記の方位差は，粒界を構成す る粒 A の結晶方位を粒 B の結晶方位に一致させるための 回転行列から求めた回転軸周りの回転角である. 各試料 においてインデンテーション試験を行った表面に対する $\left\{\begin{array}{lll}1 & 1 & 1\end{array}\right\}$ 極点図を Fig. 4 に示す. Fig. 4 を見ると, 試料 1 お よび試料 2 では法線方向が比較的近いすべり面が存在す ることから，粒界を挟む各結晶粒には，平行に近いすべ り面が存在していることがわかる。一方，試料 3 では， 結晶 3A と結晶 3B のすべり面の法線方向はいずれも離れ ているため, 粒界を挟んで 2 つの結晶粒のす心゙り面はい ずれも大きく傾いているといえる.

\section{$3 \cdot 1$ 転位密度の定義}

\section{3 結晶塑性解析}

本報では初期転位密度などの材料の微視的情報を実験 結果から同定し，数值解析で転位密度分布を直接観察す るために, 転位の情報を硬化則に導入した転位一結晶塑性 モデルを用いて解析を行う。転位密度の定義に関しては 著者ら ${ }^{19)}$ が提案した転位蓄積に基づくスカラー転位密度 を用いる. Fig. 5 のように，あるすべり系の転位運動を考 えるとき微小すべり $d \gamma$ は

$$
d \gamma=\frac{d x}{c}
$$

で与えられる. Fig. 5 において, 代表体積は $a, b$ および $c$ によって与えられ, $d x$ は転位運動に起因寸る微小せん 断変位を表す。代表体積を 1 本の転位が通過すると Burgers ベクトルの大きさ分のせん断変位が生じるので, 式(1)を用いれば, 微小すべり $d \gamma$ を引き起こすのに必要な 代表体積を通過する転位の本数 $d n_{d}$ は

$$
d n_{d}=\frac{d x}{\tilde{b}}=\frac{c \cdot d \gamma}{\tilde{b}}
$$

と表される。ここで， $\tilde{b}$ は Burgers ベクトルの大きさであ る. Orowan ループのように, 転位線がその一部分を残し ながら林立転位を通過することを仮定すれば，転位運動 によって蓄積する転位の密度 $d \rho_{a}$ が

$$
d \rho_{a}=\frac{n_{f} \cdot d n_{d} \cdot r}{a b c}
$$

と求まる，ここで， $n_{f}$ はすべり面を貫く林立転位の本数 であり， $r$ は残留転位の平均長さである. 式(2)を式(3)に 代入すれば，転位密度とすべりの関係が

$$
d \rho_{a}=\frac{r \rho_{f}}{\tilde{b}} d \gamma
$$

のように得られる.ここで, $\rho_{f}=n_{f} / a b$ は林立転位密度で ある. 式(4)から, 蓄積転位密度の発展式が次式のように 得られる.

$$
\dot{\rho}_{a}^{(\beta)}=\frac{r \rho_{f}}{\tilde{b}}\left|\dot{\gamma}^{(\beta)}\right|
$$

ここで， $\dot{\gamma}^{(\beta)}$ はすべり速度である. 転位密度速度 $\dot{\rho}_{d}^{(\beta)}$ は, 次式のように転位の蓄積と消滅のバランスによって決定 
される.

$$
\dot{\rho}_{d}^{(\beta)}=\dot{\rho}_{a}^{(\beta)}-\dot{\rho}_{r}^{(\beta)}
$$

ここで, $\dot{\rho}_{r}^{(\beta)}$ は対消滅などに起因して減少する転位の密 度である. 動的回復現象が現存する転位と蓄積した転位 の対消滅であると仮定すれば， $\dot{\rho}_{r}^{(\beta)}$ は

$$
\dot{\rho}_{r}^{(\beta)}=k \rho_{d}^{(\beta)} \dot{\rho}_{a}^{(\beta)}
$$

で与えられる。ここで， $k$ は転位の対消滅率である. 式(7) の形式は， $k$ の意味はモデルによって異なるものの, 動 的回復現象を表現するのにしばしば用いられる ${ }^{19), 20)}$. 式 (5)および式(7)を式(6)に代入すれば，転位密度速度が次式 のように得られる.

$$
\dot{\rho}_{d}^{(\beta)}=\left(1-k \rho_{d}^{(\beta)}\right) \frac{r \rho_{f}}{\tilde{b}}\left|\dot{\gamma}^{(\beta)}\right|
$$

式(8)から， $k \rho_{d}^{(\beta)}$ が 1 に達すると転位密度速度が零になる ことから， $k$ の逆数は転位密度の飽和值を意味している ことがわかる。

\section{$3 \cdot 2$ 転位-結晶塑性モデル}

結晶塑性タイプの弾塑性構成式は

$$
\stackrel{\nabla}{\boldsymbol{T}}=\boldsymbol{C}^{e}: \boldsymbol{D}-\boldsymbol{C}^{e}: \sum_{\alpha}\left(\boldsymbol{s}^{(\alpha)} \otimes \boldsymbol{m}^{(\alpha)}\right)_{S} \dot{\gamma}^{(\alpha)}
$$

で与えられる，ここで， $\boldsymbol{C}^{e}$ は異方性弾性係数テンソルお よび D は変形速度テンソル， $\boldsymbol{s}^{(\alpha)}$ はすべり方向ベクトル， $\boldsymbol{m}^{(\alpha)}$ はすべり面の法線方向ベクトルおよび ( ) テンソルの対称部分であり, $\left(\boldsymbol{C}^{e}: \boldsymbol{D}\right)_{i j} \equiv C_{i j k l}^{e} D_{k l}$ である。 ま た， $\boldsymbol{T}^{\nabla}$ は Cauchy 応力の共回転速度であり，

$$
\stackrel{\nabla}{\boldsymbol{T}} \equiv \dot{\boldsymbol{T}}-\boldsymbol{W}^{*} \boldsymbol{T}+\boldsymbol{T} \boldsymbol{W}^{*}
$$

で与えられる。式(10)において， $\boldsymbol{W}^{*} \equiv \boldsymbol{W}-\boldsymbol{W}^{p}$ は下部構造 スピン, $\boldsymbol{W}$ は連続体スピンおよび $\boldsymbol{W}^{p}$ は塑性スピンであ る。塑性スピンは $\boldsymbol{s}^{(\alpha)}$ および $\boldsymbol{m}^{(\alpha)}$ を用いて

$$
\boldsymbol{W}^{p} \equiv \sum_{\alpha}\left(\boldsymbol{s}^{(\alpha)} \otimes \boldsymbol{m}^{(\alpha)}\right)_{A} \dot{\gamma}^{(\alpha)}
$$

で表される，ここで，(）、は 2 階のテンソルの反対称部 分を意味する. 寸べり速度 $\dot{\gamma}^{(\alpha)}$ は, 次式のす心゙り速度依存 型硬化則を用いて表現される.

$$
\dot{\gamma}^{(\alpha)}=\dot{\gamma}_{0}^{(\alpha)}\left[\frac{\tau^{(\alpha)}}{g^{(\alpha)}}\right]\left[\left|\frac{\tau^{(\alpha)}}{g^{(\alpha)}}\right|\right]^{1 / m-1}
$$

ここで， $\dot{\gamma}_{0}^{(\alpha)}$ は参照すべり速度， $m$ はひずみ速度感度指 数および $\tau^{(\alpha)}$ は分解せん断応力であり,

$$
\tau^{(\alpha)}=\left(\boldsymbol{s}^{(\alpha)} \otimes \boldsymbol{m}^{(\alpha)}\right) \cdot \boldsymbol{T}
$$

で与えられる．また， $g^{(\alpha)}$ は流れ忘力であり，その発展 式は

$$
\dot{g}^{(\alpha)}=\sum_{\beta} h^{(\alpha \beta)}\left|\dot{\gamma}^{(\beta)}\right|,
$$

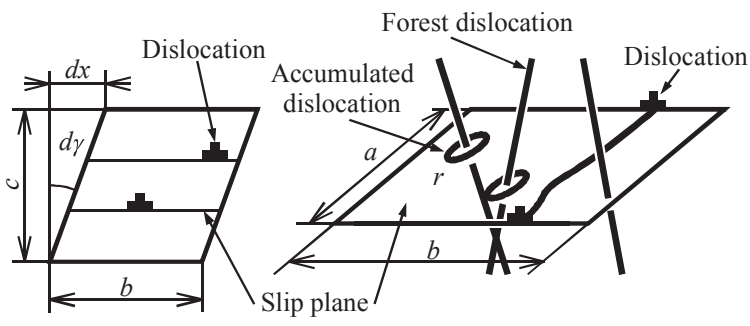

Fig.5 Definition of accumulated dislocation density ${ }^{17}$.
で表される。ここで， $h^{(\alpha \beta)}$ はすべり系間の相互作用を表 現する硬化係数である. 拡張 Bailey-Hirsch の式を時間微 分し，その結果に式(8)を代入すれば，硬化係数が

$$
h^{(\alpha \beta)}=\frac{a \mu r}{2} \Omega^{(\alpha \beta)} \frac{\rho_{f}}{\sqrt{\rho_{d}^{(\beta)}}}\left(1-k \rho_{d}^{(\beta)}\right) .
$$

と求まる。ここで， $\Omega^{(\alpha \beta)}$ は転位相互作用行列 ${ }^{21)}, a$ は 0.1 のオーダの数值パラメータおよび $\mu$ は剛性率である. 本研究では, 林立転位密度 $\rho_{f}$ は他のすべり面の転位密度 の総和で与える.

\section{$3 \cdot 3$ 解析モデルおよび材料パラメータ}

本解析では前節の結晶塑性モデルを用い, 粒内および 粒界に球状圧子を押し込むこと想定した有限要素解析を 行った. Fig. 6(a)および(b)に，インデンテーション試験に おける粒内に相当する単結晶モデルおよび粒界に相当す る双結晶モデルを示す. 単結晶および双結晶モデルの試 験片サイズおよび要素形状は同じであり，双結晶モデル の両結晶に同一の結晶方位を与えることによって単結晶 を表現した。試験片の形状は円柱であり，圧痕直径およ び押込み深さに対して十分な大きさになるように, 直径 を $300 \mu \mathrm{m}$ および高さを $300 \mu \mathrm{m}$ とした. 試験片は 129,025 個の四面体 1 次要素によって分割されており, 節点数は 22,938 である. 圧子は試験片の上面中央に押し込まれ,

Fig. 7 に示すように, 押込み位置に近づくにつれて要素サ

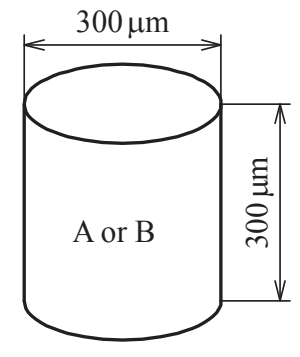

(a) Single crystal model

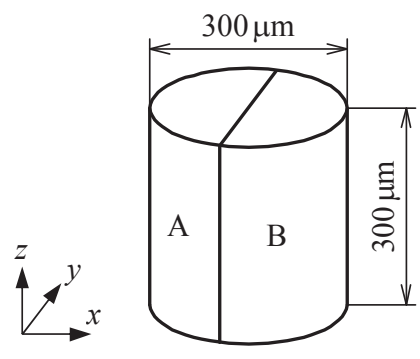

(b) Bicrystal model
Fig. 6 Computational models for single crystal and bicrystal.

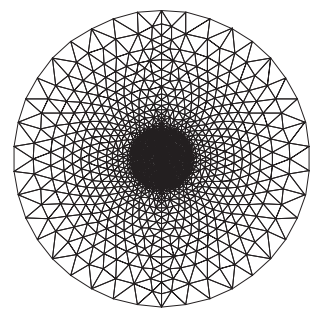

(a) Top surface

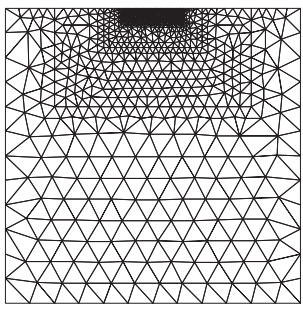

(b) Section along grain boundary

Fig. 7 Mesh shape of the computational model.

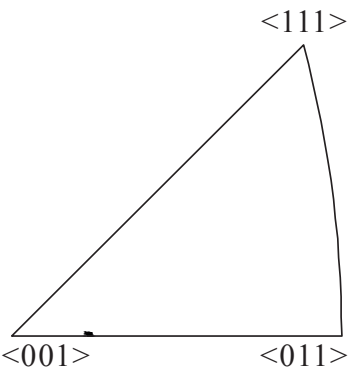

Fig. 8 Inverse pole figure for the grain used for identification of material parameters. 
イズは小さくなっている. 圧子は半径 $50 \mu \mathrm{m}$ の球状剛体 であり，試験片表面との摩擦は無視した。底面の節点を 全方向に対して拘束し，圧子押込み速度は $0.1 \mu \mathrm{m} / \mathrm{s}$ およ び最大押込み荷重は $0.294 \mathrm{~N}$ とした. 圧子と接触した節点 に圧子の半径方向への強制変位を与えることによってイ ンデンテーション試験を模擬した．結晶方位には Table 1 の EBSD 法で測定したものを用いた.

実験では測定が困難な初期転位密度，消滅率および残 留転位長さといった材料パラメータは，粒内に対するイ ンデンテーション試験で得られた荷重一変位曲線を数值 解析の結果と比較することによって同定した. フィッテ イングに用いた結晶粒の結晶方位を表す Euler 角は $\varphi_{1}=200.5 \mathrm{deg}, \phi=11.3 \mathrm{deg}$ および $\varphi_{2}=179.1 \mathrm{deg}$ であり , Table 1 のものとは異なる. Fig. 8 に圧子押込み方向（ $z$ 軸 方向）に対する逆極点図を示す．Fig. 3 における各粒の方 位とは異なっていることが確認できる. Fig. 9 にインデン テーション試験の結果と解析によって得られた荷重一変 位曲線を示す. Fig. 9 において, 最大押込み荷重における 変位の微小な差は, インデンテーション試験において最 大押込み荷重で $1 \mathrm{~s}$ 保持したことで生じる押込みクリープ に起因するものである. 同定した材料パラメータは初期 転位密度 $\rho_{0}=1.2 \times 10^{10} \mathrm{~m}^{-2}$, 消滅率 $k=1 \times 10^{15} \mathrm{~m}^{2}$ および残 留転位長さ $r=45 \mathrm{~nm}$ である。 その他の材料パラメータは 文献 19) と同一とし， $C_{11}=108.2 \mathrm{GPa}, C_{12}=61.3 \mathrm{GPa}$ ， $C_{44}=28.5 \mathrm{GPa}, \tau_{0}=1 \mathrm{MPa}, \dot{\gamma}_{0}=0.001 \mathrm{~s}^{-1}, \tilde{b}=0.286 \mathrm{~nm}$, $m=0.005$ および $a=0.1$ とした。 以降の数值解析では特に 断りのない場合は上記の值を用いる。なお，上記のよう な 1 種類の結晶に対するインデンテーション試験による 同定では，上記の材料パラメータが普遍的に定まらない ことに注意されたい。これは, 初期転位密度, 消滅率, 残留転位長さの組み合わせ次第で同様の荷重-変位曲線 が得られるためである. 複数の結晶方位の単結晶に対し てインデンテーション試験を行い, すべての荷重一変位曲 線に解析結果をフィッティングさせることによってより 妥当な材料パラメータが得られるが，そのためには，実 験計画法や応答曲面法などを用いるための膨大な量の計 算結果を必要とする．本報では転位一結晶塑性モデルを用 いた数值解析の結果からインデンテーション試験におけ る粒界の力学挙動を考察することを目的とし, 材料パラ メータの同定には 1 種類の結晶に対しての夕行う。より 妥当な材料パラメータの同定に関しては今後の課題とす る.

\section{$3 \cdot 4$ 解析結果および考察}

Fig. 10 に数值解析によって得られた圧子の最大押込み 深さと実験結果を比較したものを示す. 解析から得られ た各粒内（結晶 $\mathrm{A}$ および結晶 $\mathrm{B}$ ）の最大押込み深さの平 均と粒界（双結晶）の最大押込み深さを比較すると, 試 料 1 では粒界の最大押込み深さの方が大きく, 試料 3 で は粒界の最大押込み深さの方が小さい。この傾向は実験 結果と同様である。しかしながら, 試料 2 の解析結果は 実験結果とは異なり，粒界の最大押込み深さが粒内の最
大押込み深さの平均值とほぼ同じであり, 粒 $2 \mathrm{~A}$ と粒 $2 \mathrm{~B}$ の最大押込み深さの相対的な関係も実験結果と逆の関係 を示している. また, 試料 3 についても実験結果と解析 結果における最大押込み深さの相対的な大小の関係は同 じであるが，実験で得られた最大押込み深さが全体的に 解析で得られたものよりも小さい.

Fig. 11 にEBSD 法によって測定した圧痕周辺の結晶法 と解析によって求まった結晶方位の分布を示す. Fig. 11 における色分けの方法は Fig. 2 と同様であり, 圧子押込み 方向からの観察結果である. Fig. 11 の実験結果において 黒色の領域は変形によって観察面の傾きが変化したため に測定ができなかった領域であり，観察面が大きく傾斜 している圧痕内部の分布の信頼度は低い. Fig. 11 を見る と, 解析の圧痕サイズの方が小さいのがわかる.これは, 解析では圧子の押込みによって試験片の上面が全体的に 沈みこんだためである。本報では球状圧子を用いている が，結晶の異方性に起因して結晶の回転の仕方が場所に よって異なっている. 圧痕周辺の結晶方位の変化の傾向 は実験と解析でよく似ている. また, 試料 2 の結晶方位 分布を比較すると, 粒 $2 \mathrm{~A}$ および粒 $2 \mathrm{~B}$ ともに結晶方位に 差があるのがわかる．実際の材料では粒内においても結 晶方位にばらつきがあるが, 本解析では実験で得られた 1 点のデータを用いて均一な結晶として解析を行った. 選 択した 1 点のデータ点の值では結晶の状態を表現できな

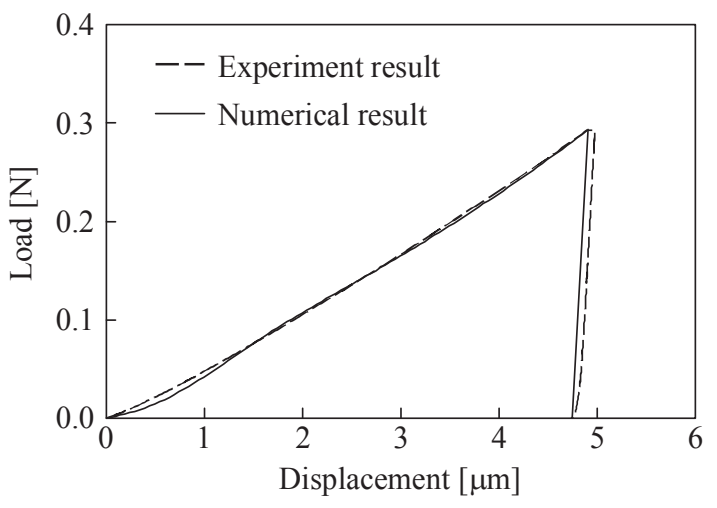

Fig. 9 Load-displacement curves obtained by the crystal plasticity simulation with an experimental result.

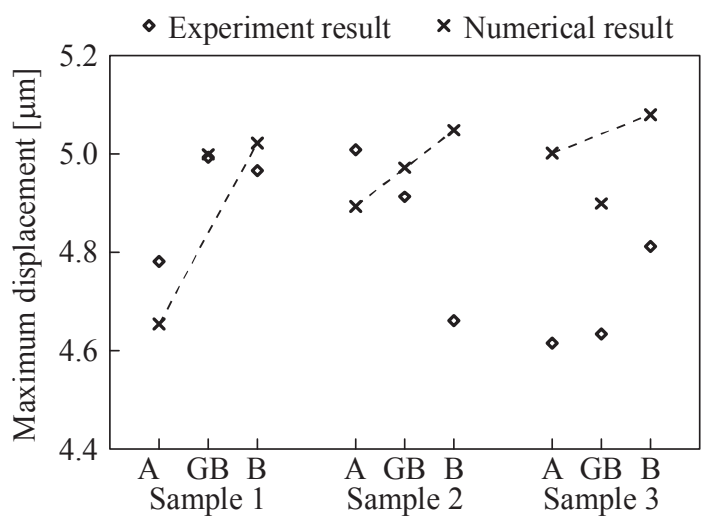

Fig. 10 Maximum displacement of indenter for the single crystals (A and B) and the grain boundary (GB) of each sample with the experiment results. 

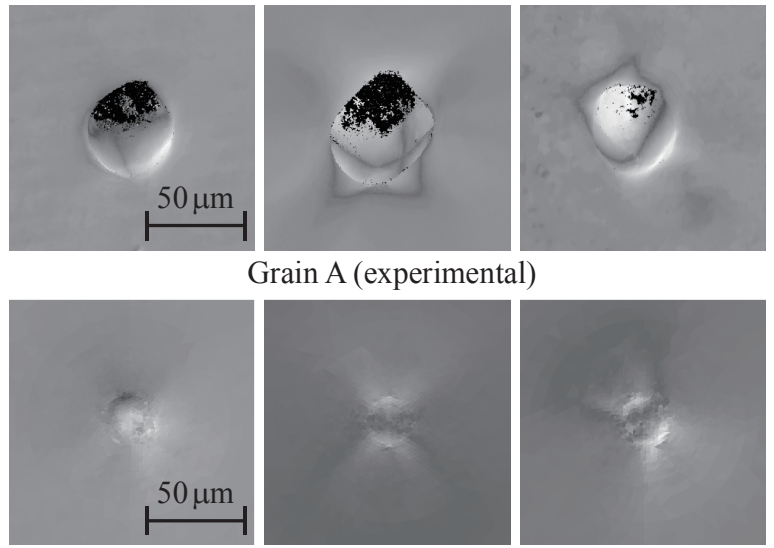

Grain A (numerical)

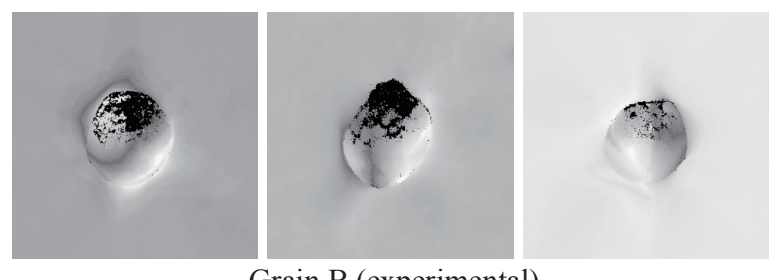

Grain B (experimental)
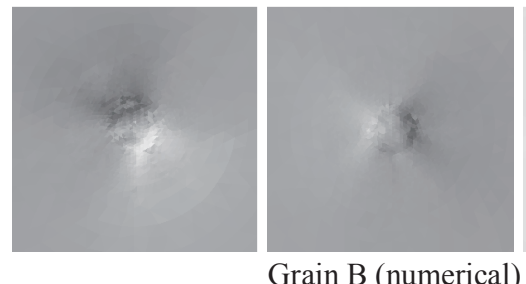

(a) Sample 1 (b) Sample 2

(c) Sample 3

Fig. 11 Distributions of crystal orientation around indentation obtained by experiment and calculation.

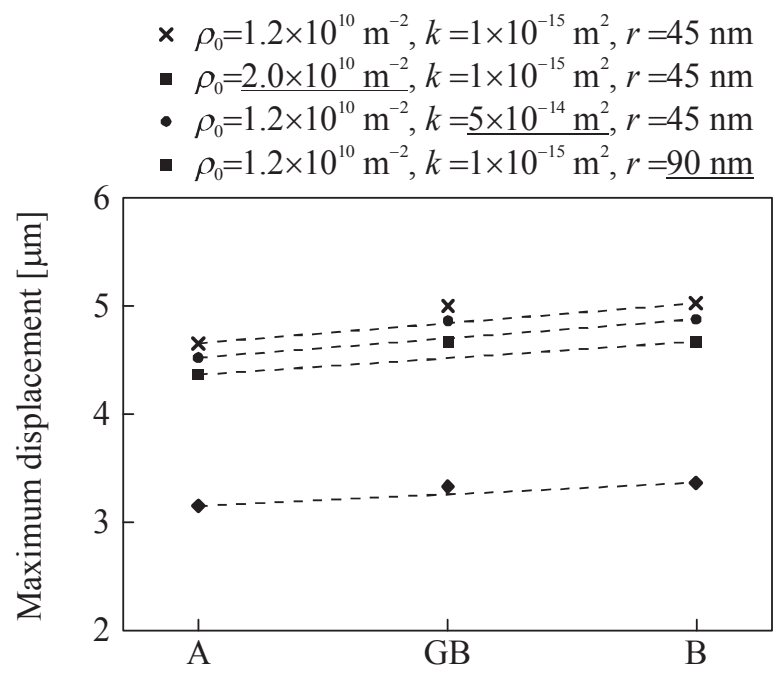

Fig. 12 Maximum displacement of indenter for the sample 1 with different initial dislocation densities, annihilation ratio and mean length of the remaining dislocation lines.

かったため，粒 2 においては Fig. 10 のような最大押込み 深さに逆の傾向がでてしまったのだと考えられる.

圧子押込み深さに影響を与える他の因子として，フィ ッティングによって同定した初期転位密度, 消滅率およ び残留転位長さが挙げられる．Fig. 12 に初期転位密度, 消滅率および残留転位長さを変化させた際の試料 1 に対 する圧子の最大押込み深さを示す。粒内，粒界に対する

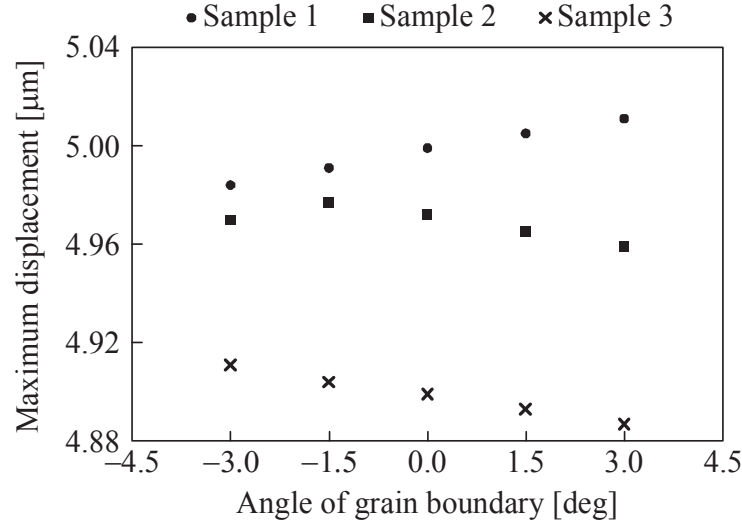

Fig. 13 Maximum displacement of indenter for different angles of grain boundary.

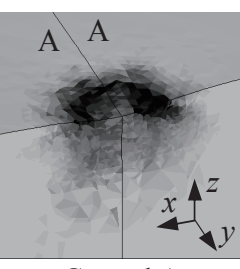

Crystal A

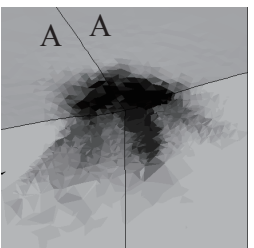

Crystal A

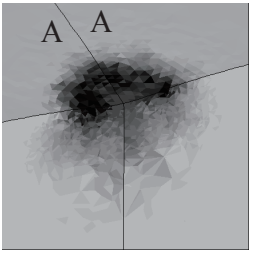

Crystal A

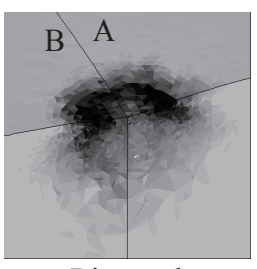

Bicrystal

(a) Sample 1

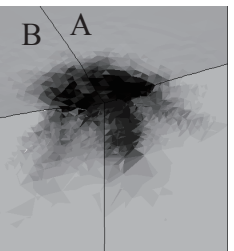

Bicrystal

(b) Sample 2

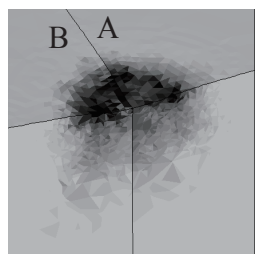

Bicrystal

(c) Sample 3

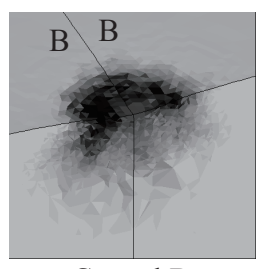

Crystal B

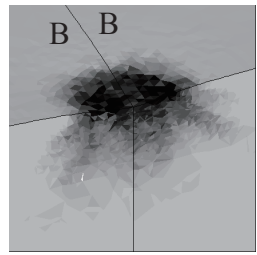

Crystal B

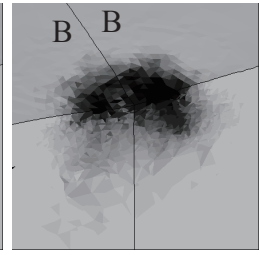

Crystal B

\section{$0 \mathrm{~m}^{-2} \quad 1 \times 10^{16} \mathrm{~m}^{-2}$ \\ Fig. 14 Distributions of total dislocation density} around indenter.

值の相対的な大小関係はいずれの条件でも同様であるが, 転位密度が大きくなると圧子押込みによる塑性変形への 抵抗が大きくなるため, 最大押込み深さは小さくなる. 残留転位長さの変化に対する最大押込夕深さの変化量は, 初期転位密度および消滅率に比べて大きい。本報で用い た転位一結晶塑性モデルにおいては，消滅率は転位の飽和 值の逆数に相当し, 残留転位長さは転位の蓄積率, 寸な わち加工硬化率を支配する. そのため, 転位密度の絶対 值よりも加工硬化率の変化が圧子の最大押込夕深さに影 響を与えているといえる。これは，転位の蓄積率が大き いと，圧痕周辺でも容易に加工硬化が進行するためであ ると考えられる。このように, 初期転位密度, 消滅率お よび残留転位長さによって最大押込み深さは増減するた め, 前述のとおり, 1 種類の結晶に対するインデンテーシ 
ヨン試験による同定では，上記の材料パラメータが普遍 的に定まらない，そのため，結晶方位によっては試料 3 にように最大押込み深さが実験值より大きくなるといっ た結果が得られたのだと考えられる。

次に粒界の角度について検討した。本数值解析で用い ている結晶方位は，実験で測定したものを用いている. しかしながら，Fig. 2 に示すように，実験における試験片 の粒界は直線ではない, そこで, 粒界を $z$ 軸周りに回転さ せた場合の解析を行った. Fig. 13 に各試験片における粒 界の角度を変化させた際の最大押込み深さの変化を示す. Fig. 13 から，各試験片において粒界の角度は最大押込み 深さに影響を与えているものの，その影響は大きくはな いことがわかる。

Fig. 14 は圧痕周辺における全すべり系の転位密度を足 し合わせた全転位密度の分布図である。Fig. 14 は圧痕直 下における $z x$ 平面の断面の分布を示しており，比較のた め単結晶 $\mathrm{A}$ および $\mathrm{B}$ の解析モデルにおいても粒界を表す 実線を表示している. Fig. 14 を見ると, 初期結晶方位に 依存して各単結晶の転位密度分布に違いが生じているの がわかる．双結晶モデルの分布は，双結晶を構成する二 つの結晶と同じ方位の単結晶の分布をちょうどつなぎ合 わせたような分布になっている。試料 1 の結晶 A では紙 面右側の領域の転位密度が高く, 結晶 B では紙面左側の 領域の転位密度が高い。試料 1 の双結晶は結晶 $\mathrm{A}$ および 結晶 $\mathrm{B}$ の転位密度が高い領域をつなぎ合わせたことにな る。前述のとおり，転位密度の絶対值は最大押込み深さ に大きく影響を与えないが，転位密度が高い領域は塑性 ひずみも高く，圧子の押込みに対して塑性変形しや寸い 領域であるといえる。 そのため，双結晶の最大押込み深 さが結晶 $\mathrm{A}$ および結晶 $\mathrm{B}$ の平均值よりも大きくなったの だと考えられる.試料 3 では試料 1 と逆の傾向が見られ, 転位密度の低い領域をつなぎ合わせたために双結晶の最 大押込み深さが小さくなっている。一方，Fig. 4 からもわ かるように，試料 2 は押込み方向に対する対称性が高い ため, 平均的な最大押込み深さになったのだと推測され る。このように，粒界を構成する結晶粒の異方性に起因 して最大押込み深さの差が生じ, 粒界における力学挙動 は結晶粒の組み合わせによって異なることが示唆される.

\section{4 結 言}

本研究では，インデンテーション法を用いた粒界の力 学特性の評価を目的とし，粒内および粒界におけるイン デンテーション試験から得られた圧子の最大押込み深さ を比較した。また，結晶方位が力学特性に及ぼす影響に ついて EBSD 法を用いた方位測定によって検討した。さ らに, 力学特性に対する粒界の影響因子および機構の検 討を目的として，転位の挙動を考慮した結晶塑性解析を 用いることでインデンテーション試験を想定した数值解 析を行った. 本研究で得られた結果を以下に示す.

(1) インデンテーション試験から得られる粒界の最大押 込み深さは，粒界を構成する結晶粒の最大押込み深 さの平均と一致せず，その増減は結晶方位に依存す
る.

（2）粒界の力学特性は，2つの結晶粒が持つすべり面同士 の相対的位置関係に影響を受け，粒界を挟む結晶の すべり面が傾いているほど, 粒界における硬化が生 じる.

（3）結晶方位に関する材料の異方性が粒界の力学特性に 影響を与える．また，加工硬化率が上昇することに よって圧子の最大押込み深さが小さくなる.

\section{参 考 文 献}

1) T. Ohmura, A. M. Minor, E. A. Stach and J. W. Morris, "Dislocation-grain boundary interactions in martensitic steel observed through in situ nanoindentation in a transmission electron microscope", Journal of Materials Research, Vol. 19, No. 12, pp. 3626-3632 (2004).

2) Y. Kim, B. Yoo, I. Choi, M. Seok, J. Kim, T. Ohmura and J. Jang, "Martensitic phase transformation and pop-in in compression of austenitic steel nanoplates observed in situ by transmission electron microscopy", Materials Letters, Vol. 75, pp. 107-110 (2012).

3) B. L. Adams, "Orientation imaging microscopy: application to the measurement of grain boundary structure", Materials Science and Engineering A, Vol. 166, Nos. 1-2, pp. 59-66 (1993).

4) B. L. Adams, S. I. Wright and K. Kunze, "Orientation imaging: the emergence of a new microscopy", Metallugical Transactions A, Vol. 24, No. 4, pp. 819-831 (1993).

5) A. J. Schwartz, M. Kumar, B. L. Adams and D. P. Field, "Electron backscatter diffraction in materials science second edition" (2009) Springer.

6) R. Seltzer, A. P. Cisilino, P. M. Frontini and Y. W. Mai, "Determination of the Druker-Prager parameters of polymers exhibiting pressure-sensitive plastic behavior by depth-sensing indentation", International Journal of Mechanical Science, Vol. 53, No. 6, pp. 471-478 (2011).

7) W. B. Lee and Y. P. Chen, "Simulation of micro-indentation hardness of FCC single crystals by mechanism-based strain gradient crystal plasticity", International Journal of Plasticity, Vol. 26, pp. 1527-1540 (2010).

8) Y. Zhang, Y. Gao and L. Nicola, "Lattice rotation caused by wedge indentation of a single crystal: Dislocation dynamics compared to crystal plasticity simulations", Journal of the Mechanics and Physics of Solids, Vol. 68, pp. 267-279 (2014)

9) H. Liang, C. H. Woo, H. Huang, A. H. W. Ngan and T. X. $\mathrm{Yu}$, "Crystalline plasticity on copper (0 01 1), (1 110$)$, and $\left(\begin{array}{lll}1 & 1 & 1\end{array}\right)$ surfaces during nanoindentation”, Computer Modeling in Engineering \& Sciences, Vol. 6, No. 1, pp. 105-114 (2004).

10) T. Tsuru, Y. Kaji, D. Matsunaka and Y. Shibutani, "Incipient plasticity of twin and stable/unstable grain boundaries during nanoindentation in copper", Physical Review B, Vol. 82, No. 2, pp. 1-6 (2010).

11) T. Ohashi, M. Kawamukai and H. Zbib "A multiscale approach for modeling scale-dependent yield stress in 
polycrystalline metals" International Journal of Plasticity, Vol. 23, pp. 897-914 (2007).

12) N. Ohno and D. Okumura, "Higher-order stress and grain size effects due to self-energy of geometrically necessary dislocations", Journal of the Mechanics and Physics of Solids, Vol. 55, No. 9, pp. 1879-1898 (2007).

13) Z. L. Liu, Z. Zhuang, X. M. Liu, X. C. Zhao and Z. H. Zhang, "A dislocation dynamics based higher-order crystal plasticity model and applications on confined thin-film plasticity", International Journal of Plasticity Vol. 27, pp. 201-216 (2011).

14) Y. Gao, Z. L. Liu, X. C. You and Z. Zhuang, "A hybrid multiscale computational framework of crystal plasticity at submicron scales". Computational Materials Science, Vol. 49, pp. 672-681 (2010).

15) Y. Aoyagi and K. Shizawa, "Multiscale crystal plasticity modeling based on geometrically necessary crystal defects and simulation on fine-graining for polycrystal", International Journal of Plasticity, Vol. 23, pp. 1022-1040 (2007)

16) Y. Aoyagi, R. Kobayashi, Y. Kaji and K. Shizawa, "Modeling and simulation on ultrafine-graining based on multiscale crystal plasticity considering dislocation patterning", International Journal of Plasticity, Vol. 47, pp. 13-28 (2013).

17) H. Lim, M. G. Lee, J. H. Kim, B. L. Adams and R. H. Wagoner, "Simulation of polycrystal deformation with grain and grain boundary effects", International Journal of Plasticity, Vol. 27, pp. 1328-1354 (2011).

18) E. Nes, B. Holmedal, E. Evangelista and K. Marthinsen, "Modelling grain boundary strengthening in ultra-fine grained aluminum alloys", Materials Science and Engineering. Vols. 410-411, pp. 178-182 (2005).

19) Y. Aoyagi, T. Tsuru and T. Shimokawa, "Crystal plasticity modeling and simulation considering the behavior of the dislocation source of ultrafine-grained metal", International Journal of Plasticity, Vol. 56, pp. 43-57 (2014).

20) U. Essmann and H. Mughrabi, "Annihilation of dislocations during tensile and cyclic deformation and limits of dislocation densities". Philosophical Magazine A, Vol. 40, pp. 731-756 (1979).

21) T. Ohashi, "Finite-element analysis of plastic slip and evolution of geometrically necessary dislocations in fcc crystals". Philosophical Magazine Letters, Vol. 75, No. 2, pp. 51-57 (1997). 